\title{
The Ottawa Field-Naturalists' Club Awards for 2017, presented February 2018
}

\author{
Eleanor Zurbrigg, Irwin Brodo, Julia Cipriani, Christine Hanrahan, and Karen McLachlan \\ HAMILTON
}

On February $24^{\text {th }}, 2018$, members and friends of the Ottawa Field-Naturalists' Club (OFNC) gathered for the Club's Awards Night at St. Basil's Church in Ottawa to celebrate the presentation of awards for achievements in the previous year. Awards are given to members or non-members who have distinguished themselves by accomplishments in the field of natural history and conservation or by extraordinary activity within the Club.

Four Club awards were presented for 2017, for: (1) redesigning Trail \& Landscape, (2) long time service for the Events Committee, (3) advocacy and science to ban the hunt of Snapping Turtles (Chelydra serpentina) in Ontario, and (4) nature-based education in Ottawa.

As well, a President's Prize was presented and a new award was announced - the James Fletcher Awardthat is issued by the Publications Committee.

\section{Member of the Year Award: Annie Bélair}

This award recognizes a member judged to have contributed the most to the Club in the previous year.

Annie Bélair has been an active member since she joined in 2004, but in 2017 her contributions were exceptional.

When Annie became Editor of Trail \& Landscape (T\&L) in 2016, one of her goals was to revamp the publication, giving it a more contemporary look for its $50^{\text {th }}$ anniversary in 2017. She began by looking at publications from other natural history clubs. Then mock-ups were produced by a professional graphic designer and reviewed by the Publications Committee. With these mock-ups as inspiration, and with the committee's suggestions in mind, Annie sprang into action. The result is the publication you see today.

Initially the plan was to create the new look by changing T\&L to the current standard magazine-size format and to move away from its black-and-white style. The transformation was gradual, beginning with colour images (made possible by a generous bequest to the OFNC) in the first two issues of 2017. The complete reveal was seen in July's special anniversary issue where margins were reduced, creating less white space, titles were changed in size, and a new multi-coloured writing style was incorporated throughout. Some images now occupy an entire page while others bleed onto the fac-

ing one. And the front cover will be different with each issue, highlighting an article found within. The new version of T\&L is quite eye-catching. Creating the makeover was no easy task. To produce the 79-page anniversary issue, Annie spent 8-12 hours each and every weekend day and 1-2 hours each night during the week for the entire month of May and the beginning of June. She formatted the articles she received, contacted Club members to acquire images, and even wrote articles herself to fill the gaps she saw with respect to content fitting for this special issue. The final version was one extremely large document that she had to split it into sections so it could be submitted to the printer electronically. Then she had to make sure all the sections were compiled correctly. It takes an extremely focussed individual to accomplish all this within a six week production window.

In 2017, Annie's contribution to the Club was not solely as Editor of T\&L. She sat on the Board of Directors and was a member of the Publications Committee, where she contributed to all the meetings. She was also involved in the redesigning of the OFNC website, and continued to help with the Macoun Club and the Awards Night. Where did she find the time?

What a year it was for Annie, our Member of the Year.

(Prepared by Karen McLachlan Hamilton)

\section{George McGee Service Award: Julia Cipriani}

This award is given in recognition of a member who has contributed significantly to the smooth running of the Club over several years.

This year, Julia Cipriani is the recipient of the 2017 George McGee Service Award. Julia probably needs little introduction, for she has been involved with so many OFNC activities that she is well-known. Julia joined the

OFNC in 2004, and within a few years was volunteering her time and energy to any number of club projects and initiatives.

From 2007 to 2013, she was a keen volunteer with the Fletcher Wildlife Garden's Butterfly Meadow project, which relies heavily on dedicated people to maintain the habitat. In the earlier days, when Julia became 
involved, the meadow was still in the process of being expanded and revamped, and Julia was instrumental in helping create the Butterfly Meadow we see today.

Earlier still, in 2006, Julia joined the OFNC Board of Directors, where she served for several years as a Member-at-Large. Later she re-joined the Board as Chair of the Events Committee from 2014 through 2016.

Julia has been a key participant in the very active Events Committee (previously, Excursions and Lectures) from 2007 to the present, both as a member, and as the Chair. Being extremely organized, she contributes greatly to the smooth operation of this committee. It is not unknown for her to arrange more than a dozen events a year, and as another member of the committee said, "We would not have the same number or breadth of events without the work she does". She is also ever on the lookout for people to serve as trip leaders, or to give presentations at the monthly meetings. Even at the Awards Night, she does not rest, but seeks out any potential new leaders or presenters willing to contribute their expertise. Julia says that she enjoys learning about the natural world, and this fuels her determination to continue looking for people who can introduce the beauty and wonder of nature to others. She says that being an extrovert and feeling comfortable talking to strangers helps! It is also her low-key but passionate approach that makes it hard for them to say "no". In addition, she gives tremendous encouragement to other committee members, and provides them with guidance and tools which enable them to be important

\section{Conservation Award - Member: David Seburn}

This award recognizes an outstanding contribution by a member in the cause of natural history conservation in the Ottawa Valley, with particular emphasis on activities within the Ottawa District.

This year David Seburn is the recipient of the Conservation Award - Member for his determination and contributions to the effort to ban the Snapping Turtle hunt in Ontario.

David Seburn spent 20 years as an independent amphibian and reptile ecologist, and is now the freshwater turtle specialist for the Canadian Wildlife Federation. $\mathrm{He}$ is a member of the Ottawa Field-Naturalists' Conservation and Publications committees and chair of the Canadian Herpetological Society's conservation committee.

In 2012, David was awarded the Ottawa Field-Naturalists Club's award for Conservation for his significant efforts in turtle research and conservation in the Ottawa area. He was part of a group that unsuccessfully lobbied the Ontario government to ban the Snapping Turtle hunt at that time.

The Ontario government designated the Snapping Turtle as a Species at Risk, but held on to their position to retain the hunt. When the Ontario government opened comments on changes to the provincial hunting contributors to the Events Committee. Julia also attends almost every OFNC monthly meeting, and many of the field trips, helping to make sure they run smoothly. Furthermore, Julia has hosted all but one of the committee meetings at her house since 2012. And she provides not only a warm and welcoming atmosphere, but snacks too.

In addition to her busy engagement with the Events Committee, Julia was also very active with the Soiree/ Awards Night from 2008 to 2016. Initially, she volunteered to help find gifts for the silent auction, visiting businesses such as Focus Scientific, Wild Birds Unlimited, and many more. Soon enough, however, she also began to take on more of a role in preparing the food for the Awards Night, and then, from 2011 to 2016, she purchased the food for the event, a not inconsiderable job, as well as continuing to help with preparation.

During Ann MacKenzie's term as OFNC President, Julia worked with her on ways to expand and engage membership. As part of this initiative, she co-facilitated several sessions seeking ideas on how to garner interest in the OFNC.

And last, but not least, Julia has been a keen member of the Awards Committee since 2009, providing valuable ideas and input, writing citations, and helping with a variety of necessary tasks.

For all these reasons and more, we are pleased to honour Julia Cipriani with the 2017 George McGee Service Award.

\section{(Prepared by Christine Hanrahan, using much of Jakob Mueller's nomination)}

regulations in 2016, there was renewed interest in trying to end the hunt. David held his position that the hunt was not based on science and publicized the risks Snapping Turtles face, including habitat loss, persecution, and road kill. It can take 20 years or more for an individual turtle to mature, making it difficult for populations to rebound from losses. Adult females are particularly vulnerable to road kill during the nesting season when they are looking for places to lay their eggs. When females do successfully lay eggs, their nests are often raided by foxes, Raccoons (Procyon lotor), and other predators.

David worked with many naturalist organizations, including our own Ottawa Field-Naturalists' Club and Ontario Nature to engage and motivate others to ask the Ontario government to end the Snapping Turtle hunt. He helped keep the short-sightedness of the hunt in the news and on social media. The Ontario government received more than 11000 comments calling for the end of the Snapping Turtle hunt, and in early 2017 the hunt was finally banned. The turtle is currently listed as a species of "Special Concern".

On their website, Ontario Nature acknowledges that, "It was a collaborative journey of dogged determination, fueled by letters to ministers, petitions, reports, 
opinion editorials, action alerts, blogs, and social media campaigns. When the going got tough, the fair and informed coverage by the press and by the Environmental Commissioner of Ontario helped immensely to buoy weary spirits and keep the issue in the public eye".

David was a key player in the process. He used his powers of persuasion via the internet to keep the issue in the news. A brief search of the subject will give rise to several links describing his tenacious effort to keep the hunt in view.
It is for his promotion and advocacy to ban the hunting of Snapping Turtles in Ontario, that the OFNC is pleased to present David Seburn with the Conservation Award for a Member for 2017.

(Prepared by Julia Cipriani. Material from the Ontario Nature website was accessed January 2018, http://www.ontarionature.org/connect/blog/at-longlast-an-end-to-the-snapping-turtle-hunt)

\section{Mary Stuart Education Award: Teachers of Regina Street Alternative School}

This award is given to a member, non-member, or organization, in recognition of outstanding achievements in the field of natural history education in the Ottawa Region.

We at the OFNC firmly believe that the well-being of the natural world in the near and distant future lies in the love of nature that is developed in the young. Unless young people are fortunate enough to have access to natural history clubs like the Macoun Field Club, their appreciation of nature is usually acquired through experiences they have with their family and the lessons they learn at school, especially if they have teachers such as those at the Regina Street Alternative School.

This school, situated adjacent to Mud Lake in the Britannia area, has over the past six years developed an extraordinary program of general learning based on exposing their students to a variety of outdoor experiences. Essentially, the teachers have made Mud Lake part of their school. The teachers have both brought nature into the classroom and used the natural environment as the classroom.

Robert James, the principal of the school, describes it as follows: "On a weekly basis students go down to Mud Lake with an educational focus. It could be anything from a math activity to a writing exercise. Students are able to share a common experience in a natural setting and take control of their own learning". For example, math classes explored mathematical patterns in nature and then found out how to determine the height of a tree using geometry, how to display data

\section{President's Prize: Adrienne Jex and Greg Lutick}

This award is given at the President's discretion in recognition of a member for unusual support of the Club and its aims.

For 2017, I would like to acknowledge the service given by Adrienne Jex and Greg Lutick.

Adrienne and Greg are the resourceful and dependable couple who about four years ago took over the refreshment table at our club's monthly meetings, shortly after we moved into the Neatby Building facility. They have successfully coped with a difficult situation - the water is far away and plugs for the electric kettles are inconvenient and they need to come early to heat the water and set up their table. They invested in results using graphs, and how to calculate probabilities with regard to the occurrence of natural events. Social Studies classes included drawing maps, finding out how various levels of government preserve natural spaces, and First Nations connections with the environment.

The outdoor projects continue into the school hallways with artwork and conversations, undoubtedly inspiring other students to explore the area. Kathleen Turner, of the MacSkimming Outdoor Education Centre, notes that, "The staff at Regina ... have learned along with their students. Their curiosity and motivation to explore the natural environment has not only brought the students' learning to life, but has also helped shape an observant, kind, and curious community of students". The students have, in turn, inspired their parents' interest in the natural world, not surprising because, as we all know, we often learn much from our children.

The imaginative and resourceful teachers at Regina Street School have become mentors throughout the Ottawa-Carleton District School Board based on their experience with inquiry-based lesson plans and classroom management techniques using outdoor spaces. Because of their inspired and inspiring leadership in natural history education, the elementary school teachers at the Regina Street Alternative School are the 2017 winners of the OFNC's Mary Stuart Education Award.

(Prepared by Irwin Brodo)

equipment to keep the brewed coffee hot and at most monthly meetings we are treated to their homemade goodies, the most imaginative being the cupcake moths that they made for the talk on Moths and Mothing. These were particularly relished. When Adrienne and Greg cannot make a monthly meeting, they see to it that somebody else is covering for them.

For their dependability, creative imagination, and for adding a special touch to our monthly meetings, I wish to award Adrienne and Greg the President's Prize for 2017. Diane Lepage, President) 


\section{James Fletcher Award: Diana Bizecki Robson, John H. Wiersema, C. Barre Hellquist, and Thomas Borsch}

New in 2017, the James Fletcher Award recognizes the best paper published in The Canadian Field-Naturalist in a particular volume, commencing with volume 130 (2016). The award is administered by the Publications Committee of The Ottawa Field-Naturalists' Club.

The first recipients of this new award are Diana Bizecki Robson, John H. Wiersema, C. Barre Hellquist, and Thomas Borsch for their paper entitled "Distribution and ecology of a new species of water-lily, Nymphaea loriana (Nymphaeaceae), in Western Canada", Canadian Field-Naturalist 130(1): 25-31. https://doi. org/10.22621/cfn.v130i1.1787. The paper describes an extensive field investigation of the distribution and ecology of a newly described aquatic plant species endemic to the Prairie Boreal Region of Canada. It represents foundational research on a new taxonomically important species and will be referred to for decades to come.

Congratulations to authors Robson, Wiersema, Hellquist, and Borsch, who have been sent personal copies of the award certificate.

(Prepared by Annie Bélair based on material from Dan Brunton and Jeffery Saarela, see Canadian Field-Naturalist 131(3): 285. https://.doi.org/10.22621/cfn.v131i3.2071 